\title{
OPEN Physical mechanisms driving the reversible aggregation of Staphylococcus aureus and response to antimicrobials
}

\begin{abstract}
Céline Burel $^{1 \bowtie}$, Rémi Dreyfus ${ }^{1} \&$ Laura Purevdorj-Gage ${ }^{2}$
Formation of non-sessile, auto-aggregated cells of Staphylococcus aureus contributes to surface colonization and biofilm formation, hence play a major role in the early establishment of infection and in tolerance to antimicrobials. Understanding the mechanism of aggregation and the impact of aggregation on the activity of antimicrobials is crucial in achieving a better control of this important pathogen. Previously linked to biological phenomena, physical interactions leading to $S$. aureus cellular aggregation and its protective features against antimicrobials remain unraveled. Herein, in-vitro experiments coupled with XDLVO simulations reveal that suspensions of $S$. aureus cells exhibit rapid, reversible aggregation (>70\%) in part controlled by the interplay between cellular hydrophobicity, surface potential and extracellular proteins. Changing $\mathrm{pH}$ and salt concentration in the extracellular media modulated the cellular surface potential but not the hydrophobicity which remained consistent despite these variations. A decrease in net cellular negative surface potential achieved by decreasing $\mathrm{pH}$ or increasing salt concentrations, caused attractive forces such as the hydrophobic and cell-protein interactions to prevail, favoring immediate aggregation. The aggregation significantly increased the tolerance of $S$. aureus cells to quaternary ammonium compounds (QAC). The well-dispersed cell population was completely inactivated within $30 \mathrm{~s}$ whereas its aggregated counterpart required more than $10 \mathrm{~min}$.
\end{abstract}

The Gram-positive $S$. aureus is an opportunistic pathogen able to thrive in a wide range of environments such as on dry inanimate surfaces, in body fluids or on human skin ${ }^{1}$. Traditionally, S. aureus cells have been studied as free-floating planktonic organisms but lately, multicellular communities of $S$. aureus forming biofilms have attracted more attention due to their increased resistance to antimicrobials ${ }^{2-4}$. Recently, autoaggregation has been identified to be among the first steps in building a biofilm ${ }^{5}$. In contrast with biofilms, bacteria cell aggregates are not necessarily surface attached but are free-floating. They are also generally smaller than typical biofilms, and they do not form the mushroom-like towers that have been observed with in vitro biofilm growth ${ }^{2}$. A deeper understanding of the mechanisms underlying the aggregation of $S$. aureus cells and the impact of aggregation on the activity of antimicrobials will facilitate the development of novel disinfection and therapeutic strategies. Until now, the mechanism of aggregation in bacteria has mostly relied on biological phenomena such as quorum sensing, stress response, predation pressure or homotypic interactions between the bacteria surface and/ or exogenous host proteins and molecules ${ }^{5-7}$. A different, yet complementary approach consists in viewing the suspensions of bacterial cells as colloids, and in applying principles of soft condensed matter physics to predict the behavior of living cells ${ }^{8,9}$. S. aureus is a non-motile, 1-micron spherical, negatively charged bacterium that closely resembles colloidal suspensions of particles when cultivated in a liquid medium. Destabilization of colloids and formation of aggregates can be caused by surface-surface attractive forces such as hydrophobic ${ }^{10}$ or oppositely charged ${ }^{11}$; depletion interactions $s^{9,12}$ and surface potential variations ${ }^{13}$. In this work, we demonstrate that planktonic suspension of $S$. aureus cells exhibit rapid, reversible aggregation in part driven by the bacteria surface potential and hydrophobicity. In our experiment the bacteria surface potential was governed by the $\mathrm{pH}$ and salt concentration of the extracellular medium. Bacteria cell aggregation was emphasized at low net cellular surface potential and by the presence of proteins. The consequence of such aggregation was studied in terms of bacterial tolerance to a common disinfectant, quaternary ammonium compound (QAC) and it was demonstrated

${ }^{1}$ Complex Assemblies of Soft Matter Laboratory (COMPASS), IRL 3254, CNRS-Solvay-University of Pennsylvania, CRTB, 350 George Patterson Boulevard, Bristol, PA 19007, USA. Solvay, Novecare CRTB, Bristol, PA 19007, USA. ${ }^{\boxplus}$ email: celine.burel@solvay.com 
a

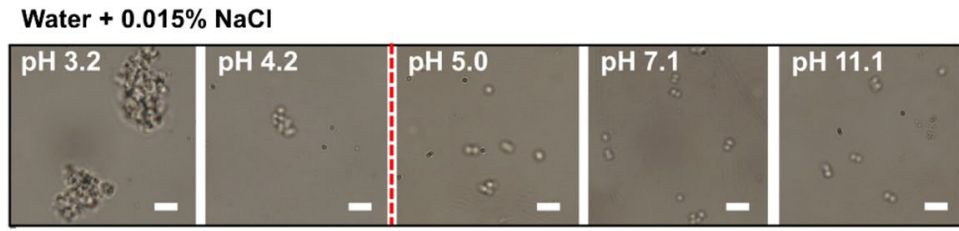

Water $+0.5 \% \mathrm{NaCl}$

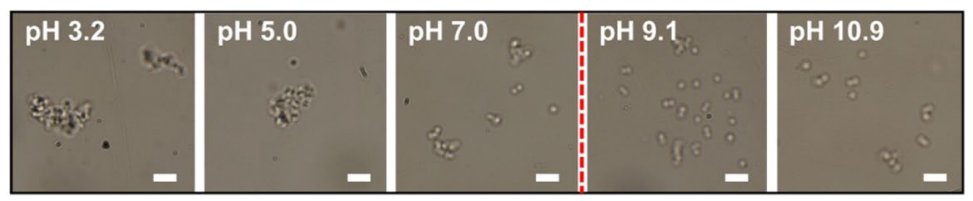

Nutrient broth
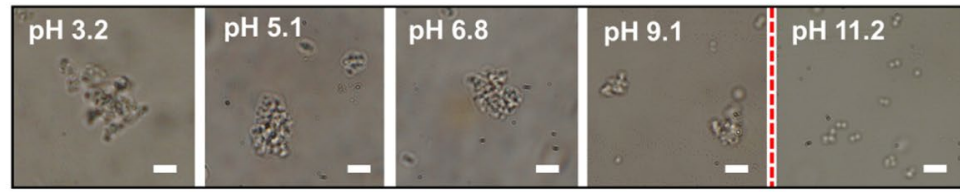

b

Water $+0.015 \% \mathrm{NaCl}$

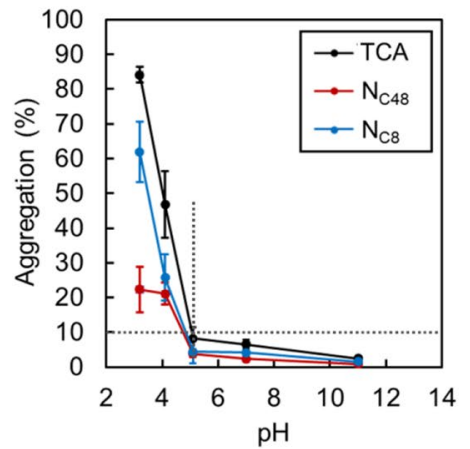

Water $+0.5 \% \mathrm{NaCl}$

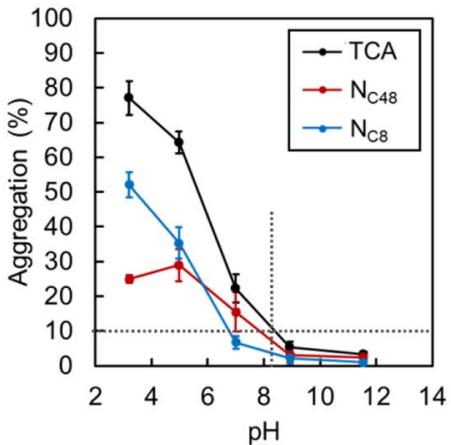

Nutrient broth

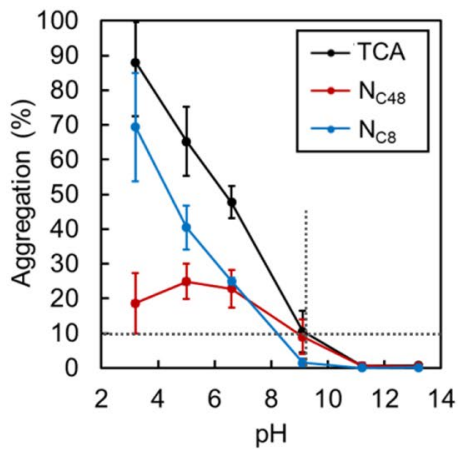

Figure 1. S. aureus cells aggregate when $\mathrm{pH}$ is decreased and salt or protein concentrations are increased. (a) Aggregation of $S$. aureus cells as a function of $\mathrm{pH}$ in water with $0.015 \%$ and $0.5 \%$ of $\mathrm{NaCl}$ and in Nutrient broth. Each scale bar is $4 \mu \mathrm{m}$. (b) Quantification of S. aureus cells aggregation as a function of $\mathrm{pH}$ in water with $0.015 \%$ and $0.5 \%$ of $\mathrm{NaCl}$ and in Nutrient broth. TCA is the total percent of cells aggregated, $\mathrm{N}_{\mathrm{C} 48}$ is the percent of cells in aggregates of sizes between 4 and $8 \mu \mathrm{m}$ and $\mathrm{N}_{\mathrm{C} 8}$ is the percent of cells in aggregates larger than $8 \mu \mathrm{m}$. The crossover of the two dashed lines indicates the value of $\mathrm{pH}_{\mathrm{Agg}}$.

that a population containing a greater fraction of aggregated cells was more than 20 times harder to kill than the one with fewer aggregates.

\section{Results and discussion}

To elucidate if physical forces can cause $S$. aureus aggregation, hydrophobicity and aggregation behavior of $S$. aureus suspended in water with low $(0.015 \%)$ and high $(0.5 \%)$ concentrations of salt $(\mathrm{NaCl})$ and in Nutrient broth was studied as a function of $\mathrm{pH}$ (Fig. 1). Nutrient broth is a proteinaceous medium used in many standardized microbiology tests. A $0.015 \%(2.6 \mathrm{mM}) \mathrm{NaCl}$ solution was selected to match the salt concentration of Nutrient broth and $0.5 \% \mathrm{NaCl}(85.6 \mathrm{mM})$ was selected because it is used in other standardized media including AOAC Nutrient broth in addition to being a concentration relevant to physiological conditions. In each media, multiple bright-field optical microscopy images of the bacterial suspensions were analyzed at several pH values ("Materials and methods" section). Overall, $S$. aureus aggregation was observed to be $\mathrm{pH}$-dependent in all three media. The aggregation occurred rapidly, in a matter of $15 \mathrm{~s}$ and the overall size of the aggregates noticeably increased as $\mathrm{pH}$ decreased (Fig. 1a). The total percent of cells aggregated ("TCA") was evaluated based on the percentage of cells that were found in aggregates of sizes larger than $4 \mu \mathrm{m}$ (Fig. 1b). An arbitrarily set $\mathrm{pH}$, denoted as $\mathrm{pH}_{\mathrm{Agg}}$, was defined as the threshold $\mathrm{pH}$ whereat 10 or more percent of the cell population were aggregated. The $\mathrm{pH}_{\mathrm{Agg}}$ values were measured at approximately 4.8, 8.0 and 9.1 in water at low and high $\mathrm{NaCl}$ concentrations, and in Nutrient broth, respectively. As $\mathrm{pH}$ dropped below the $\mathrm{pH}_{\mathrm{Agg}}$ value, a sharp increase in the overall TCA populations was observed in each medium, reaching up to $85 \%$ in water at low $\mathrm{NaCl}$ concentrations, $75 \%$ in water with $0.5 \% \mathrm{NaCl}$ and $88 \%$ in Nutrient broth. The TCA population was further subdivided into two groups based on the cross-areal diameter of individual aggregates: percent of cells in aggregates of sizes between 4 and $8 \mu \mathrm{m}$ (" $\mathrm{N}_{\mathrm{C} 48}$ ") and percent of cells in aggregates larger than $8 \mu \mathrm{m}\left(\right.$ " $\mathrm{N}_{\mathrm{C} 8}$ "). At $\mathrm{pH}<\mathrm{pH}_{\mathrm{Agg}}, \mathrm{N}_{\mathrm{C} 48}$ increases at a moderate 
a
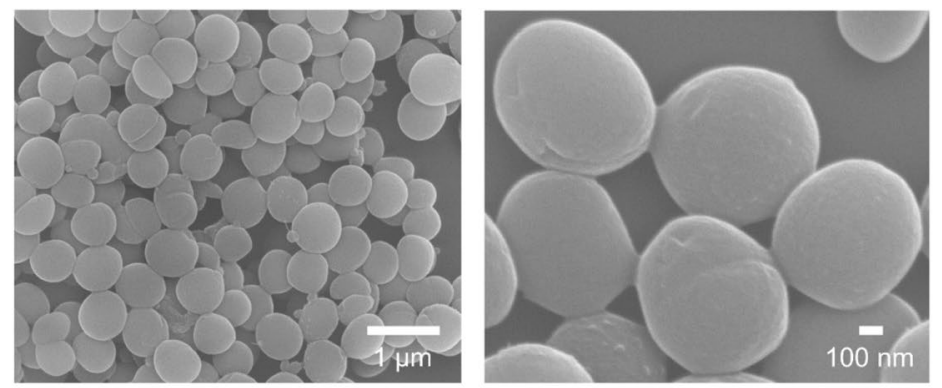

b

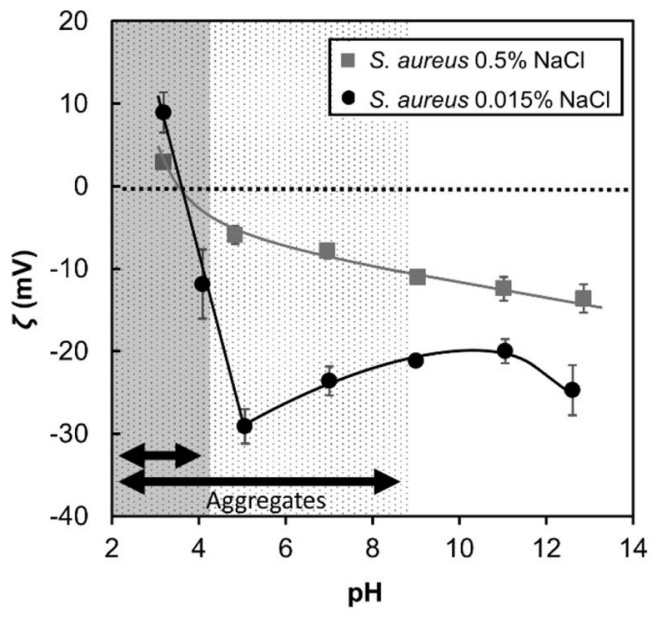

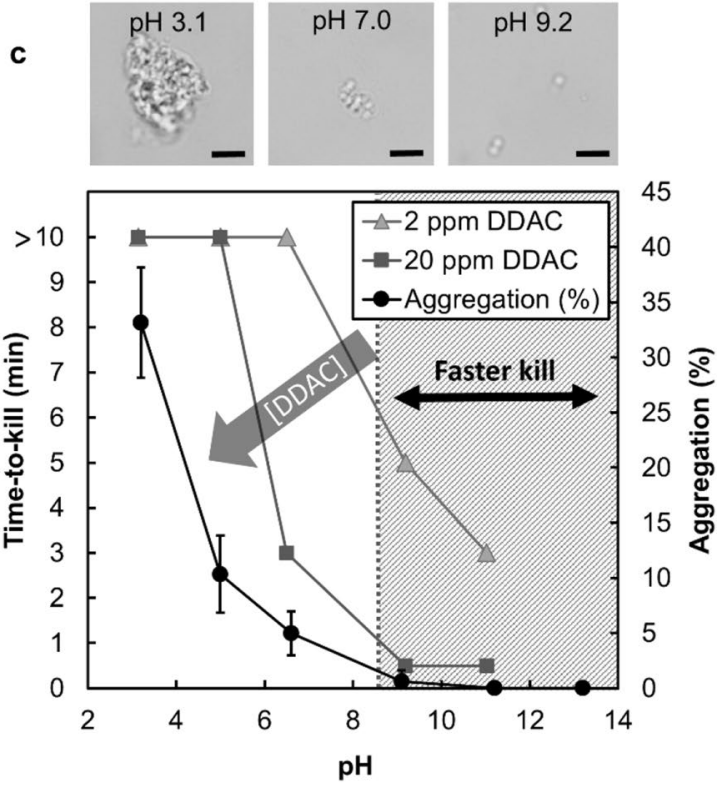

Figure 2. The aggregation of $S$. aureus depends on the potential of the cells and increases the bacterial tolerance to QACs. (a) SEM images of clustered S. aureus cells cultivated overnight in Nutrient broth ( $\mathrm{pH} 7$ ) reveal the absence of polymers or proteins in the cell clusters. (b) Surface potential of S. aureus in water with $0.015 \%$ and $0.5 \%$ of $\mathrm{NaCl}$ as a function of $\mathrm{pH}$. (c) S. aureus time-to-kill as a function of DDAC concentration and $\mathrm{pH}$ (each datum point corresponds to three determinations with identical results) and simulated $S$. aureus $\left(7 \log _{10} \mathrm{CFU} /\right.$ $\mathrm{mL}$ ) aggregation as a function of $\mathrm{pH}$. Optical microscopy images of $S$. aureus $\left(7 \log _{10} \mathrm{CFU} / \mathrm{mL}\right)$ aggregates observed at 3 different $\mathrm{pH}$ values. Each scale bar is $4 \mu \mathrm{m}$.

rate to the reach maximum values of $20-29 \%$ whereas $\mathrm{N}_{\mathrm{C} 8}$ continuously increased, leading to the final values of $62 \%, 52 \%$ and $69 \%$ for water at low and high salt concentrations and for Nutrient broth, respectively. These observations could be explained by the formation of new aggregates in combination with the growth of already formed aggregates as $\mathrm{pH}$ dropped. Further analyses revealed that, in all three media, aggregates of sizes larger than $8 \mu \mathrm{m}$ grew both in size and in number at $\mathrm{pH}$ below the $\mathrm{pH}_{\mathrm{Agg}}$ value (see Fig. $\mathrm{S} 1$ in the Supplements). In summary, when salt or proteins were present at physiologically relevant concentrations, the aggregation of $S$. aureus was enhanced. Indeed, the $\mathrm{pH}_{\mathrm{Agg}}$ values shifted towards greater values along with more than $25 \%$ of the cell population existing in aggregates of at least $8 \mu \mathrm{m}$ in size at larger $\mathrm{pH}$ values $(\mathrm{pH} 5$ and 6.5 for $0.5 \% \mathrm{NaCl}$ and Nutrient broth as compared to $\mathrm{pH} 4.2$ in $0.015 \% \mathrm{NaCl}$ ).

In this work, the aggregation of $S$. aureus occurred in a matter of seconds upon change of the extracellular $\mathrm{pH}$ and salt content. Additionally, SEM imaging of cells grown in Nutrient broth at $\mathrm{pH} \sim 7$ ("Materials and methods" section) did not reveal external web-like polymers or protein matrices surrounding the bacterial cells (see Fig. 2a). These observations suggest that the mechanism of aggregation in S. aureus may not derive from changes in cellular metabolism or from de-novo synthesis of adhesive factors (both requiring a longer time for gene expression and protein synthesis) as previously thought by Haaber et $\mathrm{al}^{6}$. Since the overall surface potential of bacteria is $\mathrm{pH}$ - and salt-dependent ${ }^{14}$, it is possible that the rapid aggregation observed in $S$. aureus could, in fact, be due to changes in the bacterial surface potential. We measured the surface potential of $S$. aureus as a function of $\mathrm{pH}$ at $0.015 \%$ and $0.5 \% \mathrm{NaCl}$. Results presented in Fig. $2 \mathrm{~b}$ show that the absolute surface potential of $S$. aureus becomes less negative as $\mathrm{pH}$ decreases. Indeed, the zeta potential $(\zeta)$ of bacteria dispersed in water with $0.015 \% \mathrm{NaCl}$ increases from $-25 \mathrm{mV}(7<\mathrm{pH}<11)$ to $+10 \mathrm{mV}(\mathrm{pH} 3)$. By decreasing the net surface potential, the electrostatic repulsion between the cells also decreased thereby causing aggregation. The addition of $0.5 \%$ of $\mathrm{NaCl}$ shifted the entire set of $|\zeta|$ values upwards on the zeta potential graph, indicating an overall decrease in the surface potential across the entire $\mathrm{pH}$ range studied. This behavior is characteristic of charge screening by salt in colloidal suspensions, as reported by Leckband and Israelachvili ${ }^{13}$ and resulted in a greater aggregation in water 
with $0.5 \%$ of $\mathrm{NaCl}$ as compared to $0.015 \% \mathrm{NaCl}$ (Fig. 1b). In addition to surface potential, hydrophobic interactions can play an important role in cell-cell aggregation ${ }^{13}$. The hydrophobicity of $S$. aureus cells was measured ${ }^{15}$ and the results presented in Fig. S2 in Supplements showed the S. aureus strain used herein to be hydrophobic (in alignment with the results of Reifsteck et al. ${ }^{10}$ regardless of the extracellular $\mathrm{pH}$ or salt content. Simulations of $S$. aureus aggregation using an extended DLVO model ${ }^{16-19}$ (XDLVO, see Fig. S3 in Supplements) revealed that without this hydrophobic property (modeled by attractive hydrophobic forces ${ }^{13}$ ), cells carrying a strong negative potential at $\mathrm{pH} 5-7$ (below $\mathrm{pH}_{\mathrm{Agg}}$ ), would not aggregate in water with $0.5 \%$ of $\mathrm{NaCl}$. Indeed, across the $\mathrm{pH}$ range 3-12, the hydrophobic attractive forces are about twice as large as the Van Der Waals attractive forces. In Nutrient broth, the surface potential of bacteria is expected to be similar to the surface potential of bacteria dispersed in water containing a matching salt concentration of $0.015 \% \mathrm{NaCl}$. However, as compared to water with $0.015 \% \mathrm{NaCl}$, the aggregation of $S$. aureus was considerably enhanced in Nutrient broth $\left(\mathrm{pH}_{\mathrm{Agg}}\right.$ is shifted from 4.8 to 9.1). While Nutrient broth is a complex medium, proteins such as the ones it contains have already been reported to promote cell aggregation via several mechanisms ${ }^{5,13}$ including depletion and bacterial cells bridging. In our study, the two latter potential mechanisms could have been enhanced at low $\mathrm{pH}$ due to decrease in the net surface potential and aggregation of proteins contained in Nutrient broth (see Fig. S4 in Supplements).

The consequence of $S$. aureus cell aggregation was studied in relation to bacterial tolerance to QACs, which are broad-spectrum antimicrobials ${ }^{20,21}$ commonly used in disinfectant and sanitizer formulations. QACs are membrane-active agents comprising a positively-charged head which electrostatically interacts with the negatively charged bacteria membrane, and a hydrophobic tail which can penetrate into the membrane ultimately leading to membrane structural damages and bacteria lysis ${ }^{20}$. Suspensions of cells $\left(6.7 \log _{10} \mathrm{CFU} \mathrm{mL} \mathrm{mL}^{-1}\right)$ in Nutrient broth were adjusted to $\mathrm{pH}$ values between 3 and 11. Then, each sample was challenged with either 20 or $2 \mathrm{ppm}$ of Didecyldimethylammonium chloride (DDAC) for $30 \mathrm{~s}, 1,2,5$ and 10 min ("Materials and methods" section). The minimum time required to inactivate the entire cell population (time-to-kill) was plotted as a function of $\mathrm{pH}$. Results presented in Fig. $2 \mathrm{c}$ show that for both DDAC concentrations, the time-to-kill values decrease with increasing $\mathrm{pH}$ with the shortest time-to-kill values observed at $\mathrm{pH} 9$ and 11 (see Tables S1 and S2 in Supplements). Two parts per million (ppm) of DDAC at $\mathrm{pH} 9$ were sufficient to achieve a complete kill within 5 min of exposure time. Increasing both DDAC concentration and $\mathrm{pH}$ drastically reduced the time-to-kill. Indeed, we report a complete deactivation of $S$. aureus within seconds (30 s) of exposure to $20 \mathrm{ppm}$ of DDAC at pH 9, compared to $3 \mathrm{~min}$ being required at $\mathrm{pH}$ 6.5. As $\mathrm{pH}$ is decreased from 7 to 3.2, the prediction of the aggregation for $6.7 \log _{10} \mathrm{CFU} / \mathrm{mL}$ yield aggregation of $35 \%$ of the cell population (see Fig. S5 in Supplements). Overall, $S$. aureus cells are less sensitive to DDAC when the bacterial surface is less negatively charged and the cell population is more aggregated. Interestingly, a tenfold increase in the DDAC concentration reduced the time-to-kill from more than $10 \mathrm{~min}$ to $3 \mathrm{~min}$ at $\mathrm{pH} 6.5$ whereas a diminution of the time-to-kill was not observed at lower $\mathrm{pH}$ values ( $\mathrm{pH} 5$ and 3 ). As previously shown, when $\mathrm{pH}$ decreased, the proportion of aggregated cells increased, with larger and more numerous aggregates forming at the lowest $\mathrm{pH}$ values. Additionally, in low $\mathrm{NaCl}$ conditions such as found in Nutrient broth or water with $0.015 \% \mathrm{NaCl}$, the bacterial surface potential measured at $\mathrm{pH} 7$ and pH 9 (Fig. 2b) were comparable $(\zeta \sim-22 \mathrm{mV}$ ); whereas the aggregation of cells was greater at $\mathrm{pH} 7$ than it was at $\mathrm{pH}$ 9. Thus, the superior antimicrobial efficacy observed with DDAC at $\mathrm{pH} 9$ as compared to $\mathrm{pH} 7$ cannot be attributed to the difference in the electrostatic attraction between negatively-charged bacteria and positivelycharged QACs. We therefore, speculate that the increased tolerance to QACs observed at low $\mathrm{pH}$ values were likely driven by the physical barrier provided by cellular aggregation.

Bacterial aggregates including sessile biofilms often rely on external shear forces or secretion of enzymes to disperse $^{2,22}$. To determine whether the aggregation in S. aureus is reversible, we imaged aliquots of $S$. aureus cells at $\mathrm{pH}$ adjusted to 3 , and then raised to 9 . The process was repeated in a different set of identical samples starting from $\mathrm{pH} 9$ and then lowered to $\mathrm{pH}$ 3. Results presented in Fig. 3a show the aggregation to be reversible in all three media studied. Indeed, aggregates formed at $\mathrm{pH} 3$ rapidly dispersed when the $\mathrm{pH}$ was raised to 9 . Similarly, the singlet cells observed at $\mathrm{pH} 9$ quickly aggregated when the $\mathrm{pH}$ was lowered to 3 . This behavior suggests that in low $\mathrm{pH}$ ranges, the net surface potential of bacteria is small enough such that long range electrostatic interactions are overpassed by attractive interactions, thus inducing aggregation. Irreversible aggregation occurs when bacteria get extremely close to each other ${ }^{13}$. The observed reversible aggregation can be explained by the presence of a short range $(\sim 0.5 \mathrm{~nm})$ repulsive interaction ${ }^{17}$ between the bacteria, which precludes any irreversible aggregation due to Van der Waals interactions. We have included such a repulsion in our XDLVO model in water with $\mathrm{NaCl}$ (see the Supplements for more details). Standard disinfection tests such as developed by the EPA ${ }^{23}$ and the "AOAC use dilution test" 24 require the complete kill of test bacterial population within 10 min of exposure in proteinaceous media and are conducted as a qualitative assay based on turbidity similar to the methodology applied in this study. To meet such demanding standards, industrial and healthcare disinfectants often formulated at neutral $\mathrm{pH}$ (considered as an optimal $\mathrm{pH}$ for QACs performance) require the use of several thousands of ppm of QACs. Since aggregation of $S$. aureus is reversible with increasing $\mathrm{pH}$, a change in formulation $\mathrm{pH}$ would be a quite simple solution to help inactivate this bacterium more efficiently, with lower usage of biocidal actives.

To investigate whether the surface potential-mediated aggregation of $S$. aureus is a general and observable trait in other species of bacteria, we imaged Enterococcus hirae (Gram positive, non-motile) and Pseudomonas aeruginosa (Gram negative, motile) suspended in Nutrient broth and in water with $0.015 \%$ and $0.5 \% \mathrm{NaCl}$, each adjusted to $\mathrm{pH} 3,7$ and 9 . The results, presented in Fig. 3b, indicate that at $\mathrm{pH} 3$ E. hirae cells aggregated whereas $P$. aeruginosa cells did not in all three media. The aggregation of $E$. hirae occurred within a few minutes, which was slower than that of $S$. aureus. The bacterial surface potential was determined as a function of $\mathrm{pH}$ for both bacteria dispersed in water with $0.015 \%$ and $0.5 \% \mathrm{NaCl}$. The results presented in Fig. $3 \mathrm{~b}$ show that the net surface potential in $E$. hirae decreased significantly at lower $\mathrm{pH}$ values. On the contrary, the surface potential in $P$. aeruginosa decreases to a much lesser extent within the $\mathrm{pH}$ range of 2 to 12, confirming the results reported by Shephard et $\mathrm{a}^{25}$. Interestingly, in Nutrient broth, $P$. aeruginosa did not aggregate at low $\mathrm{pH}$, which could be due 
a

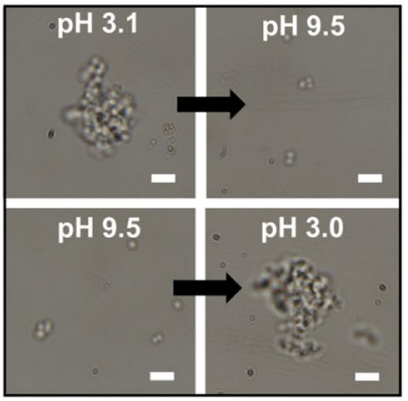

b
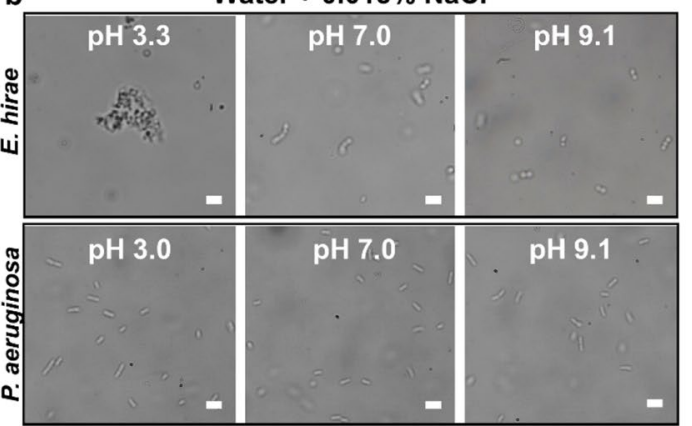

$-1$

Nutrient broth

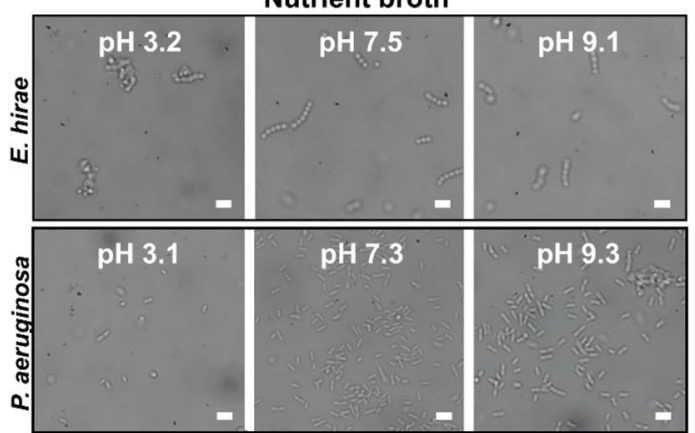

Water $+0.5 \% \mathrm{NaCl}$
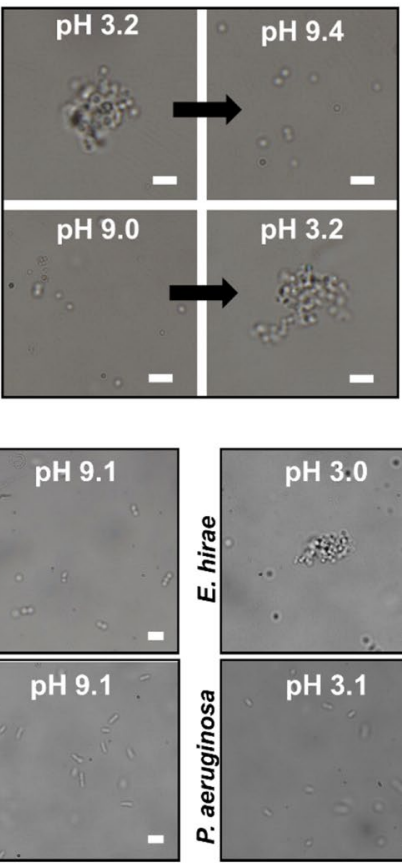

$-$
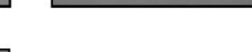

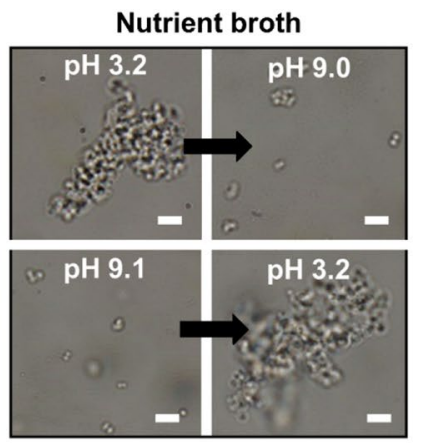

Water $+0.5 \% \mathrm{NaCl}$

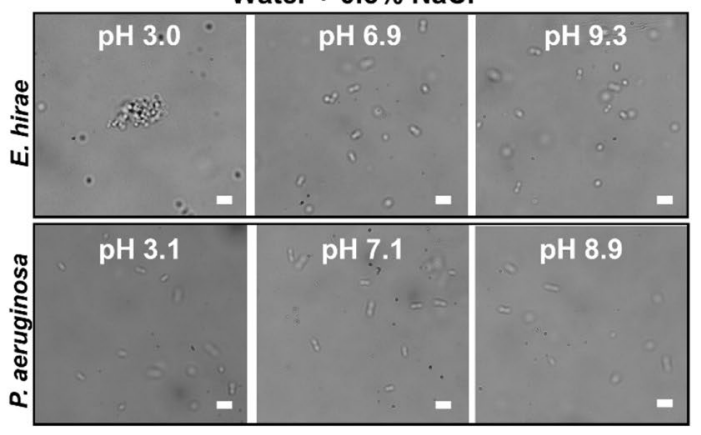

$\mathrm{pH}$

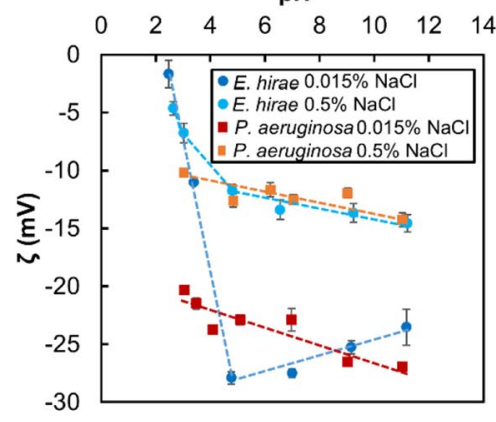

Figure 3. Cellular aggregation is reversible and specific to bacteria with a lower cell potential. (a) Reversibility of S. aureus aggregation in water with $0.015 \%$ and $0.5 \% \mathrm{NaCl}$ and in Nutrient broth. (b) Aggregation behavior of E. hirae and P. aeruginosa in water with $0.015 \%$ and $0.5 \% \mathrm{NaCl}$ and in Nutrient broth as a function of $\mathrm{pH}$. Each scale bar is $4 \mu \mathrm{m}$. Surface potential of P. aeruginosa and E. hirae suspended in water with $0.015 \%$ and $0.5 \%$ $\mathrm{NaCl}$. The dotted lines are to provide visual guidance. E. hirae aggregate at low $\mathrm{pH}$ (lower cell potential) while $P$. aeruginosa does not.

to a stronger electrostatic repulsion between the bacteria overcoming the attractive forces mediated by proteins. Indeed, as compared to E. hirae, the net surface potential of $P$. aeruginosa is higher at $\mathrm{pH}$ below 4 . These results confirm that a significant reduction in the bacterial net surface potential $(<11 \mathrm{mV})$ is necessary for cellular aggregation to occur in Nutrient broth.

In summary, the current research determined that short-time scale cellular aggregation of $S$. aureus is dependent on cell surface potential, which is governed by extracellular $\mathrm{pH}$ and salt concentration. At a higher $\mathrm{pH}$, the strongly negatively charged cells are fully dispersed, whereas at a lower $\mathrm{pH}$, cells with a lower net surface charge aggregate. The aggregation is amplified by the addition of salt due to cell surface charge screening, or proteins due to bacteria bridging or depletion. Our experiments revealed that the intrinsic hydrophobicity of S. aureus is an important bacteria feature contributing to cellular aggregation. S. aureus cellular hydrophobicity remained consistent despite variations in $\mathrm{pH}$ and salt concentrations. Additionally, our XDLVO model estimated that the hydrophobic interactions are about 2 times larger than the Van Der Waals attractive interactions. Upon decrease in net cellular negative potential, the attractive hydrophobic interactions prevail over the electrostatic repulsive interactions, hence leading to immediate aggregation. A similar surface potential driven aggregation behavior observed with $E$. hirae but not with $P$. aeruginosa suggests that bacteria with a lower net surface potential are more susceptible to aggregation. The impact of aggregation on the resistance of $S$. aureus to QACs is significant. The time-to-kill is 20 fold greater at low $\mathrm{pH}$ when aggregates are formed as compared to high $\mathrm{pH}$ where cells are dispersed. This result is in agreement with previous reports ${ }^{6}$ suggesting that bacterial aggregation provides a microenvironment in which innermost cells are protected from antimicrobial agents. Interestingly, $S$. aureus is known to acidify its extracellular medium as it multiplies in a closed batch system ${ }^{26}$. Moreover, $S$. aureus is often 
found on host $\operatorname{skin}^{7}$ which displays a slightly acidic $\mathrm{pH}$ when intact. A low $\mathrm{pH}$ environment might dissuade the growth of many organisms but may favor survival and formation of auto-aggregated populations of $S$. aureus cells that are self-protected. This protective phenotype combined with maintained mobility afforded by non-sessile aggregation, is likely to enhance survival and successful colonization of $S$. aureus under various environmental conditions. The reversible, surface potential-dependent nature of aggregation in S. aureus along other similarly charged bacteria could provide guidance to a design of more effective disinfectants and sanitizers.

This paper described aggregation behavior in S. aureus which was previously grown in the conditions required by standard disinfection test methods. Additional work is necessary to determine if similar aggregation mechanisms are applicable to other strains and growth conditions. Indeed, parameters such as bacterial strain, growth phase (exponential vs stationary), growth temperature and stock culture storage temperature (fridge vs room temperature) can impact expression profile of membrane and cell wall associated proteins. These changes in protein expressions can, in turn, affect bacterial surface charge and hydrophobicity ${ }^{10}$ ultimately impacting the forces driving the aggregation of $S$. aureus. Future investigations on these environmental variables will provide guidance on how bacterial aggregation impacts disinfection in both laboratory and real-world settings.

\section{Materials and methods}

Microbial strains. All bacterial strains were purchased from the American type culture collection (Manassas, VA, http://www.atcc.gov. Staphylococcus aureus (ATCC 6538), Pseudomonas aeruginosa (ATCC 15442) and Enterococcus hirae (ATCC 10541) cultures were maintained in a $40 \%(\mathrm{v} / \mathrm{v})$ glycerol solution at $-80{ }^{\circ} \mathrm{C}$.

Bacteria cell culture and plate counting. Fresh cultures of Staphylococcus aureus, Enterococcus hirae and Pseudomonas aeruginosa were prepared by inoculating $35 \mathrm{~mL}$ Nutrient Broth (General Laboratory Products Inc.) with a single colony isolated on a Tryptic Soy Agar (TSA, Hardy Diagnostics) plate stored at $4^{\circ} \mathrm{C}$. For $S$. aureus, the same streak plate and Nutrient broth batch were used for all experiments. We observed a standard error in $\mathrm{pH}_{\mathrm{Agg}}( \pm 0.6 \mathrm{pH}$ unit) with varying batches of streak plate and Nutrient broth. The $S$. aureus liquid cultures were then incubated overnight at $35^{\circ} \mathrm{C}$ while shaking at $150 \mathrm{rpm}$ (incubating Minishaker 12620-942, VWR International). The E. hirae and P. aeruginosa liquid cultures were incubated overnight at $37^{\circ} \mathrm{C}$ while shaking at $150 \mathrm{rpm}$. For $S$. aureus, the concentration of the overnight bacterial cultures was determined by serial dilution and plating on TSA plates. Colony forming units of bacteria per $\mathrm{mL}\left(\mathrm{CFU} \mathrm{mL} \mathrm{m}^{-1}\right)$ were counted after $24 \mathrm{~h}$ of incubation at $35^{\circ} \mathrm{C}$. The final bacterial concentration in the overnight culture was about $8 \log _{10} \mathrm{CFU} \mathrm{mL}^{-1}$ for $S$. aureus $\left(\mathrm{OD}_{600 \mathrm{~nm}} \sim 0.3\right)$. The concentrations of E. hirae and $P$. aeruginosa, were 7.3 (Nutrient Broth)/8.1(water with $\mathrm{NaCl}$ ) and $\sim 9.5 \log _{10} \mathrm{CFU} \mathrm{mL} \mathrm{mL}^{-1}$, respectively.

Aggregation study. In water with $0.015 \% \mathrm{NaCl}$. The overnight culture was centrifuged twice at $10,000 \mathrm{rpm}$ for $10 \mathrm{~min}$. The resulting bacterial pellets were re-dispersed in ultrapure water with $0.015 \% \mathrm{NaCl}$ (BioXtra) at $\mathrm{pH} 7$. The final $\mathrm{OD}_{600 \mathrm{~nm}}$ of the bacterial dispersion was 0.3 .

In water with $0.5 \% \mathrm{NaCl}$. The overnight culture was centrifuged twice at $10,000 \mathrm{rpm}$ for $10 \mathrm{~min}$. The resulting bacterial pellets were re-dispersed in ultrapure water containing $0.5 \% \mathrm{NaCl}$ (BioXtra) at $\mathrm{pH} 7$. The final $\mathrm{OD}_{600 \mathrm{~nm}}$ of the bacterial dispersion was 0.3 .

In nutrient broth. The overnight culture $\left(\mathrm{OD}_{600 \mathrm{~nm}}=0.3\right)$ was used without further dilution or wash step to mimic the culture preparation methods recommended by standard disinfection tests.

For all three media types (water with $0.015 \%$ and $0.5 \% \mathrm{NaCl}$ and Nutrient broth), the final bacterial dispersions were aliquoted into $4 \mathrm{~mL}$ samples and were adjusted to appropriate $\mathrm{pH}$ levels using either hydrochloric acid or sodium hydroxide. A gentle manual shake was performed to homogenize each sample before analysis (taking place only a few minutes after $\mathrm{pH}$ adjustment). Optical imaging and zeta potential measurements were carried out using the same overnight culture. All experiments were performed in triplicates using three independent overnight cultures.

Optical microscope imaging. For the hydrophobicity test, the optical microscopy images were acquired on a Leica TCS SP8 inverted confocal microscope in bright field and transmission mode. All the other images were acquired on an Olympus microscope in bright field and transmission mode. Images were taken with a $100 \times$ objective oil (NA 1.4). The camera used was a Sony a Nex-7 color camera.

Bacteria counts and statistical analysis. For the image analysis, a $4 \mu \mathrm{m}$ size threshold was set based on the fact that $S$. aureus cells typically form singlets, duplets, triplets and quadruplets (made of 4 one-micron cells in a clusters) whose sizes are below $4 \mu \mathrm{m}$. Bacteria were counted manually for three independent replicate experiments. Approximately 2000 bacterial cells were counted for each replicate experiment and for each $\mathrm{pH}$ value, leading to a total of more than 6000 bacterial cells for each data points. The number of bacteria aggregated in all three replicate experiments were averaged and the standard deviation of the average was used for the error bars $($ error $=S t d v / \sqrt{3})$. The size measurements of aggregates were obtained with ImageJ using the greatest crossarea length of individual aggregates from top views. The software used for the data analysis was MICROSOFT EXCEL.

Zeta potential and pH measurements. The Zeta potential of bacteria was measured on a Zetasizer Nano Serie 200. All bacterial samples were centrifuged and re-suspended in either $0.015 \%$ or $0.5 \% \mathrm{NaCl}$ aque- 
ous solutions ( $S$. aureus and P. aeruginosa were centrifuged twice at 10,000 rpm for $10 \mathrm{~min}$; E. hirae was centrifuged once at 10,000 rpm for $30 \mathrm{~min}$ ). For $S$. aureus, the surface charge for each $\mathrm{pH}$ value was measured in three independent replicates. For each replicate, three sequences of 10 measurements were performed at each $\mathrm{pH}$ value. The charge for one replicate was obtained by averaging the measurements from all three sequences. The final charge was obtained by averaging the charge obtained for the three replicates. For $P$. aeruginosa and $E$. hirae, the charge of three technical replicates (three sequences of 10 measurements) were averaged for each $\mathrm{pH}$ value. The $\mathrm{pH}$ of each bacterial dispersions was measured with a VWR Scientific digital $\mathrm{pH}$ temperature meter (model 8015).

SEM imaging. The $S$. aureus cell aggregates formed in Nutrient broth $(\mathrm{pH} 7)$ were observed by SEM. A $2 \mathrm{~mL}$ aliquot of the overnight culture was centrifuged at $10,000 \mathrm{rpm}$ for $10 \mathrm{~min}$ and the resulting pellet was re-suspended in $1 \mathrm{~mL}$ of a $0.5 \%$ glutaraldehyde PBS solution and held for $30 \mathrm{~min}$ at room temperature. The centrifugation was repeated a second time and the bacterial pellet was re-suspended in $1 \mathrm{~mL}$ of sterile MilliQ water. An aliquot of $100 \mu \mathrm{L}$ of bacteria was then drop casted onto a previously isopropanol washed silicon wafer and air dried overnight. The following day, the cells were fixed for $1 \mathrm{~h}$ with $100 \mu \mathrm{L}$ of a $0.1 \%$ glutaraldehyde solution followed by an additional $1 \mathrm{~h}$ fixation with $100 \mu \mathrm{L}$ of a $0.5 \%$ glutaraldehyde solution. Finally, the specimens were dehydrated by adding ethanol in a graded series ( $70 \%$ for $6 \mathrm{~min}, 90 \%$ for $6 \mathrm{~min}$, and 100\% for $6 \mathrm{~min}$ ). The wafers were left to air dry and coated with platinum with a Cressington sputter coater before SEM imaging using a JEOL 7500 HRSEM.

Time-to-kill study. First, 5 solutions of $90 \mathrm{~mL}$ of Nutrient broth were $\mathrm{pH}$ adjusted to 3.1, 5.0, 6.5, 9.2 and 11.0. Each solution was then divided into 3 sets of 3 solutions ( 3 replicates) each containing $10 \mathrm{~mL}$ of $\mathrm{pH}-$ adjusted Nutrient broth. In the first set, no DDAC (MAQUAT 4450-E didecyldimethylammonium chloride, Pilot chemical) was added; this series consists of untreated controls. A two ppm (final concentration) of DDAC solution was pipetted into the second set. A $20 \mathrm{ppm}$ (final concentration) of DDAC solution was pipetted into the third set. Then, an aliquot of $100 \mu \mathrm{L}$ of the overnight culture is mixed into each tube to reach a final S. aureus concentration of approximately $6.7 \log _{10} \mathrm{CFU} \mathrm{mL} \mathrm{m}^{-1}$. The samples were incubated at room temperature and were sampled at specified time intervals: $30 \mathrm{~s}, 1,3,5$ and $10 \mathrm{~min}$. At the end of each exposure time, an aliquot of $100 \mu \mathrm{L}$ of each bacterial dispersion was added into $9.9 \mathrm{~mL}$ of TAT neutralizer broth (General Laboratory Products) and vortexed for five seconds. The vials containing TAT broth were incubated at $35^{\circ} \mathrm{C}, 50 \mathrm{rpm}$ for $18 \mathrm{~h}$ (MaxQ4000 shaker, model 4342, Thermo Scientific). Viability was assessed by the presence or absence of turbidity developed post incubation. The controls were incubated at room temperature for $10 \mathrm{~min}$ and were sampled for microbial enumeration (neutralization in TAT broth followed by serial dilution in phosphate buffer and plating on TSA plates). The CFUs were counted after $24 \mathrm{~h}$ of incubation at $35^{\circ} \mathrm{C}$. The untreated controls showed no reduction in the cell population (see Table S3 in Supplements for CFUs), suggesting that $\mathrm{pH}$ alone did not significantly impact cell viability. TAT broth was previously shown to be an effective media to neutralize DDAC ${ }^{21}$.

Reversibility study. S. aureus dispersions in water with $\mathrm{NaCl}$ and in Nutrient broth were prepared as described in the aggregation study section of the "Materials and methods". For each aforementioned medium, two aliquots of $4 \mathrm{~mL}$ of $S$. aureus dispersions $\left(\mathrm{OD}_{600 \mathrm{~nm}}=0.3, \mathrm{pH} \sim 7\right)$ were adjusted to $\mathrm{pH} 3$ and $\mathrm{pH} 9$ using $\mathrm{HCl}$ and $\mathrm{NaOH}$, respectively. Then, the $\mathrm{pH}$ of the first bacterial dispersion was adjusted to $\mathrm{pH} 9$ and the second dispersion was adjusted to $\mathrm{pH} 3$. All samples were homogenized with gentle manual shake and optical microscope imaging was carried out after each $\mathrm{pH}$ adjustment. For each medium, the experiment was conducted in three independent experiments with reproducible results.

Bacterial specificity study. Aliquots $(4 \mathrm{~mL})$ of overnight cultures of $H$. hirae and $P$. aeruginosa were $\mathrm{pH}$ adjusted using either $\mathrm{HCl}$ or $\mathrm{NaOH}$. A gentle manual shake was performed to homogenize each sample before optical imaging. Two independent experiments were performed for each $\mathrm{pH}$ value with reproducible results.

XDLVO simulations. Our simulation model is based on an extended DLVO ${ }^{13,16-19}$ (XDLVO) model. It relies on the seminal model for studying the aggregation of colloids. In the DLVO model, two main interaction potential are considered: the Van der Waals interaction energy ${ }^{13}(\mathrm{VdW})$ and the electrostatic repulsion interaction ${ }^{16}$. The XDLVO model incorporated two additional interactions: an attractive hydrophobic interaction ${ }^{13,17}$ and repulsive steric interactions ${ }^{13}$. The energy landscape was computed and the energy minimum was extracted. From the value of the minimum of energy, the percentages of bacterial populations either in singlets or in aggregates were calculated ${ }^{18,19}$ (see the Supplementary information section for more details).

\section{Data availability}

All data are available from the corresponding author upon request.

\section{Code availability}

All codes are available from the corresponding author upon request.

Received: 22 May 2021; Accepted: 12 July 2021

Published online: 22 July 2021 


\section{References}

1. Lowy, F. D. Staphylococcus aureus infections. N. Engl. J. Med. 339, 520-532 (1998).

2. Bjarnsholt, T. et al. The in vivo biofilm. Trends Microbiol. 21, 466-474 (2013).

3. Davies, D. Understanding biofilm resistance to antibacterial agents. Nat. Rev. Drug Discov. 2, 114-122 (2003).

4. Paharik, E. \& Horswill, A. R. The staphylococcal biofilm: Adhesins, regulation, and host response. Microbiol. Spectr. 4, 529-566 (2016).

5. Trunk, T., Khalil, H. S. \& Leo, J. C. Bacterial autoaggregation. AIMS Microbiol. 4, 140-164 (2018).

6. Haaber, J., Cohn, M. T., Frees, D., Andersen, T. J. \& Ingmer, H. Planktonic aggregates of Staphylococcus aureus protect against common antibiotics. PLoS ONE 7, e41075 (2012).

7. Crosby, H. A., Kwiecinski, J. \& Horswill, A. R. Staphylococcus aureus aggregation and coagulation mechanisms, and their function in host-pathogen interactions. Adv. Appl. Microbiol. 96, 1-41 (2016).

8. Wilking, J. N., Angelini, T. E., Seminara, A., Brenner, M. P. \& Weitz, D. A. Biofilms as complex fluids. MRS Bull. 36, 385-391 (2011).

9. Dorken, G., Ferguson, G. P., French, C. E. \& Poon, W. C. K. Aggregation by depletion attraction in cultures of bacteria producing exopolysaccharide. J. R. Soc. Interface 9, 3490-3502 (2012).

10. Reifsteck, F., Wee, S. \& Wilkinson, B. J. Hydrophobicity-hydrophilicity of staphylococci. J. Med. Microbiol. 24, 65-73 (1987).

11. Arenas, J. et al. Involvement of three meningococcal surface-exposed proteins, the heparin-binding protein NhbA, the $\alpha$-peptide of IgA protease and the autotransporter protease NalP, in initiation of biofilm formation. Mol. Microbiol. 87, 254-268 (2012).

12. Secor, P. R., Michaels, L. A., Ratjen, A., Jennings, L. K. \& Singh, P. K. Entropically driven aggregation of bacteria by host polymers promotes antibiotic tolerance in Pseudomonas aeruginosa. PNAS 115, 4210780-4210785 (2018).

13. Leckband, D. \& Israelachvili, J. Intermolecular forces in biology. Q. Rev. Biophys. 34, 105-267 (2001).

14. Burel, C., Kala, A. \& Gage, L. Impact of $\mathrm{pH}$ on citric acid antimicrobial activity against Gram-negative bacteria. Lett. Appl. Microbiol. 72, 332-340 (2021).

15. Purevdorj-Gage, B., Orr, M. E., Stoodley, P., Sheehan, K. B. \& Hyman, L. E. The role of FLO11 in Saccharomyces cerevisiae biofilm development in a laboratory based flow-cell system. FEMS Yeast Res. 7, 372-379 (2007).

16. Kovalchuk, N. M. \& Starov, V. M. Aggregation in colloidal suspensions: Effect of colloidal forces and hydrodynamic interactions. Adv. Colloid Interface Sci. 179, 99-106 (2012).

17. Dorobantu, L. S., Bhattacharjee, S., Foght, J. M. \& Gray, M. R. Analysis of force interactions between AFM tips and hydrophobic bacteria using DLVO theory. Langmuir 25, 6968-6976 (2009).

18. Dreyfus, R. et al. Simple quantitative model for the reversible association of DNA coated colloids. Phys. Rev. Lett. 102, 048301 (2009).

19. Dreyfus, R. et al. Aggregation-disaggregation transition of DNA-coated colloids: Experiments and theory. Phys. Rev. E 81, 041404 (2010).

20. Jennings, M. C., Minbiole, K. P. C. \& Wuest, W. M. Quaternary ammonium compounds: An antimicrobial mainstay and platform for innovation to address bacterial resistance. ACS Infect. Dis. 1, 288-303 (2015).

21. Burel, C., Direur, G., Rivas, C. \& Purevdorj-Gage, L. Colorimetric detection of residual quaternary ammonium compounds on dry surfaces and prediction of antimicrobial activity using bromophenol blue. Appl. Microbiol. 72, 358-365 (2021).

22. Kaplan, J. B., Ragunath, C., Ramasubbu, N. \& Fine, D. H. Detachment of Actinobacillus actinomycetemcomitans biofilm cells by an endogenous beta-hexosaminidase activity. J. Bacteriol. 185, 4693-4698 (2003).

23. EPA. Product Performance Test Guidelines. United States Environmental Protection Agency OPPTS 810.2300: Sanitizers for Use on Hard Surfaces-Efficacy Data Recommendations. United States Environmental Protection Agency. EPA-712-C-07-091. Office of Chemical Safety and Pollution Prevention (7510P) (2012).

24. AOAC Use Dilution Method for Testing Disinfectants (955.14). US Environmental Protection Agency Office of Pesticide Programs. Microbiology Laboratory Environmental Science Center.

25. Shephard, J., McQuillan, A. J. \& Bremer, P. J. Mechanisms of cation exchange by Pseudomonas aeruginosa PAO1 and PAO1 wbpL, a strain with a truncated lipopolysaccharide. Appl. Environ. Microbiol. 74, 6980-6986 (2008).

26. Burel, C. et al. Plasmonic elastic capsules as colorimetric reversible pH-microsensors. Small 16, 1903897 (2020).

\section{Acknowledgements}

The authors acknowledge the support of the French National Agency of Research (ANR) to the project REACT through the grant ANR15-PIRE-0001-06. SEM imaging was performed in facilities supported by the NSF MRSEC program under award No DMR-1720530. The authors also thank Dr. Denis Bendejacq, Dr. Kamel Ramdani and Dr. Matthew Taylor for fruitful discussions.

\section{Author contributions}

C.B. initiated the project, designed and performed experiments, analyzed data and wrote the paper. R.D. performed simulations, analyzed data and wrote the paper. L.P.-G. designed experiments, analyzed data and wrote the paper.

\section{Competing interests}

The authors declare no competing interests.

\section{Additional information}

Supplementary Information The online version contains supplementary material available at https://doi.org/ 10.1038/s41598-021-94457-1.

Correspondence and requests for materials should be addressed to C.B.

Reprints and permissions information is available at www.nature.com/reprints.

Publisher's note Springer Nature remains neutral with regard to jurisdictional claims in published maps and institutional affiliations. 
(c) (i) Open Access This article is licensed under a Creative Commons Attribution 4.0 International cc) License, which permits use, sharing, adaptation, distribution and reproduction in any medium or format, as long as you give appropriate credit to the original author(s) and the source, provide a link to the Creative Commons licence, and indicate if changes were made. The images or other third party material in this article are included in the article's Creative Commons licence, unless indicated otherwise in a credit line to the material. If material is not included in the article's Creative Commons licence and your intended use is not permitted by statutory regulation or exceeds the permitted use, you will need to obtain permission directly from the copyright holder. To view a copy of this licence, visit http://creativecommons.org/licenses/by/4.0/.

(C) The Author(s) 2021 